\title{
Identification of Nomophobia in Primary School Age Children and its Consequences for Friendly Character Behavior
}

\author{
Ika Ari Pratiwi ${ }^{1}$, Zuhdan Kun Prasetyo ${ }^{2}$, Samsuri $^{3}$, Much Arsyad Fardani ${ }^{4}$, Tutik Khotimah ${ }^{5}$ \\ \{ika.ari@umk.ac.id', zuhdan@uny.ac.id², samsuri@uny.ac.id ${ }^{3}$, arsyad.fardani@umk.ac.id², \\ tutik.khotimah@umk.ac.id $\left.{ }^{5}\right\}$ \\ 1,4,5 Universitas Muria Kudus Gondang Manis PO. BOX 53 Bae Kudus, \\ Central Java, Indonesia Phone (+62291) 438229, Fax (+62291)437198; \\ ${ }^{2,3}$ Universitas Negeri Yogyakarta, Indonesia
}

\begin{abstract}
Mobile Phone is a communication tool without limited distance and helps in carrying out daily activities. If it cannot be managed properly, the presence of a mobile phone will be toxic to its users, especially for children. The inability of children to manage the use of mobile phones will have an adverse effect, one of which is the dependence of mobile phones known as Nomophobia (No-mobile phobia). Mobile phone dependency makes children can not be far from, want to always use a mobile phone for their own enjoyment. This article aims to identify the phenomenon of nomophobia in students of Muhammadiyah 1 Primary School Kudus. Indications of children who are dependent on mobile phones can be seen from the activities, namely: spending a long time with a mobile phone, worrying when not using a mobile phone, feeling more sensitive and preferring to use a mobile phone in activities rather than hanging out with friends. Thus, the action is needed to identify the existence of students who are indicated nomophobia and how the character development in daily life.
\end{abstract}

Keywords: nomophobia, friendly character behaviour

\section{Introduction}

The challenges of life in modern times require people to behave wisely and proportionally in responding to technological developments. Technology is currently developing so rapidly that it permeates various walks of life both individually and within the social sphere in society. Technological products that have so far developed rapidly and spawned a new generation, one of which is a mobile phone. The mobile phone is a technology that is developing rapidly and has special functions including smartphones, i-phones, and android [8]. Another opinion explains that mobile phones are sophisticated goods that are created with various applications that can present a variety of news media, social networks, hobbies and even entertainment [14]. The increasing use of new technologies and virtual communication involving personal, tablets and mobile phones are causing changes in individuals' daily habits and behavior [6]. The Indonesian nation is one of the nations involved in the advancement of information and technology media from mobile phones.

Mobile phones at this time users have penetrated to all walks of life, one of which is in elementary school-age children who use mobile phones to play games. The fact of the gadget is not only used by adults (22 years and over), adolescents (12-21), but in 
children ( 7 - 11 years), and children (3 - 6) years who should not be eligible to use mobile. phone [15]. Please note that excessive use of mobile phones for children has more negative impacts. Negative impacts caused are: time wasted, disrupting brain development, disrupting health, eliminating interest in play activities, and weakening the moral values of children with features that are not in accordance with their world [2].

The attitude and behavior of a child who is dependent on the use of a mobile phone will affect the activities and personal character of the child in daily life. Thus it is necessary to prevent negative impacts on the use of mobile phones, namely to equip children to understand the importance of character education and apply it in everyday life. Character is a way of thinking and behaving that characterizes each individual to live and cooperate both within the scope of the family, community, nation, and state [11]. Character education is an effort to educate children so they can make decisions wisely and practice them in their lives, so they can make a positive contribution to their environment.

The character that is owned by everyone will greatly affect the quality of life and social success in society. Thus it is important to be taught early on to children to be able to apply character values. Character values that are very influential on daily relationships are friendly character values. A friendly character is an act /action that shows happy to hang out, talk and cooperate with others [5]. Friendly behavior includes: Speaking politely and politely, respecting each other and maintaining respect, and communicating well [13].

Friendly character behavior needs to be taught to students through activities carried out together. Students need to be guided when interacting, so there is no grouping or gabe between students. Students should be able to get along with anyone without choosing friends. School is a good tool to instill friendly characters by interacting and socializing through teacher guidance. Instilling patient character is very important to instill in children to prevent antisocial attitudes because of the use of mobile phone information technology.

Based on the existing problems, this study was conducted to identify 4th-grade students of Muhammadiyah 1 Primary School Kudus who like to play mobile phones continuously (indicative of nomophobia) and how their friendly characters behave in relationships in school.

\section{Method}

This research method uses descriptive qualitative research. This research was carried out 4th-grade students of Muhammadiyah 1 Primary School Kudus, with a total of 25 students. In order to obtain data, the data collection techniques were carried out by questionnaire, interview and literature study. Based on the type of research and the method used, the data analysis technique in this study is a qualitative analysis according to Miles \& Huberman includes: data reduction, data presentation, and drawing conclusions [15].

The initial stage with the study of literature from several journals that examines the friendly character and addiction to the use of mobile phones. The next method is conducting interviews and surveys to 4th-grade students of Muhammadiyah 1 Primary School Kudus 
related to the intensity of students who like to play mobile phones. In order to obtain valid and reliable data in qualitative research that is tested is to use triangulation techniques by crossing or comparing the results of interviews with documents of research implementation in the field.

\section{Result and Discussion}

A child who likes to play games using a mobile phone should be cautious, because he is worried he will experience addiction to playing mobile phone (nomophobia). The characteristics of nomophobia are: 1) spending time using a mobile phone, 2) feeling anxious when the mobile phone cannot be used (weak battery, quota runs out of no signal), 3) sleeping close to the mobile phone, 4) little interaction with others and choosing using a mobile phone [12]. Indicators someone someone has experienced a mobile phone addiction (nomophobia), namely: 1) salience, 2) tolerance, 3) mood modification, 4) withdrawal, 5) relapses, 6) conflict and 7) problems [9].

In order to know the condition of students of SD Muhammadiyah 1 Kudus indicated nomphobia was done by giving questionnaires to students. Students fill out a questionnaire that students are given answer choices guided by researchers. Fill out the questionnaire modify from Lemmens et el, ie player rated all game addiction items on a 5-point continum scale: 1 (never), 2 (rarely), 3 (sometimes), 4 (often), 5 (very often) [9]. The questionnaire given to students is arranged based on nomophobia indicators, by choosing 4 answer choices below. The results of the recapitulation questionnaire were used to identify nomophobia in 4th-grade students of Muhammadiyah 1 Primary School Kudus can be seen in Table 1.

Table 1. Recapitulation of Nomophobia Identification Questionnaire In 4th-grade students of Muhammadiyah 1 Primary School Kudus

\begin{tabular}{|c|c|c|c|c|c|}
\hline \multirow{2}{*}{ No } & \multirow{2}{*}{ Statement } & \multicolumn{4}{|c|}{ Choice } \\
\hline & & never & Rarely & Sometimes & always \\
\hline 1 & $\begin{array}{l}\text { When I play games from a mobile phone I } \\
\text { don't care about other people and even } \\
\text { forget myself for example eating, bathing }\end{array}$ & 4 & 13 & 7 & 1 \\
\hline 2 & $\begin{array}{l}\text { The amount of time spent playing } \\
\text { continues to grow until I forget to study }\end{array}$ & & 17 & 8 & \\
\hline 3 & $\begin{array}{l}\text { Games from mobile phones keep me } \\
\text { entertained because I am dizzy with } \\
\text { schoolwork }\end{array}$ & 2 & 10 & 9 & 4 \\
\hline 4 & $\begin{array}{l}\text { I prefer playing mobile phone rather than } \\
\text { doing work }\end{array}$ & 11 & 12 & 2 & \\
\hline 5 & $\begin{array}{l}\text { My tasks are too late if I spend time } \\
\text { playing mobile phones }\end{array}$ & 3 & 11 & 6 & 5 \\
\hline 6 & $\begin{array}{l}\text { I feel that playing games using a mobile } \\
\text { phone makes time wasted }\end{array}$ & & 17 & 8 & \\
\hline 7 & $\begin{array}{l}\text { I am happy when I win a game from a } \\
\text { mobile phone }\end{array}$ & & 5 & 7 & 13 \\
\hline 8 & $\begin{array}{l}\text { I feel happy when leveling up or } \\
\text { discovering new games from a mobile } \\
\text { phone }\end{array}$ & 1 & 4 & 5 & 15 \\
\hline 9 & I always smile and laugh when playing & & 7 & 11 & 7 \\
\hline
\end{tabular}




\begin{tabular}{|c|c|c|c|c|c|}
\hline & games from a mobile phone & & & & \\
\hline 10 & $\begin{array}{l}\text { I refuse and argue when told by parents to } \\
\text { help when playing so that makes parents } \\
\text { angry }\end{array}$ & 5 & 8 & 6 & 6 \\
\hline 11 & $\begin{array}{l}\text { My parents make ends meet (obey) me so I } \\
\text { don't get angry }\end{array}$ & 4 & 11 & 7 & 3 \\
\hline 12 & $\begin{array}{l}\text { When I play games from a mobile phone, I } \\
\text { always increase the game level }\end{array}$ & 3 & 10 & 6 & 6 \\
\hline 13 & $\begin{array}{l}\text { I am willing to spend a lot of time playing } \\
\text { in front of a mobile phone }\end{array}$ & 12 & 7 & 3 & 3 \\
\hline 14 & $\begin{array}{l}\text { I always add time to play games from a } \\
\text { mobile phone }\end{array}$ & 10 & 8 & 3 & 4 \\
\hline 15 & $\begin{array}{l}\text { I feel uneasy when I don't play games from } \\
\text { the mobile phone a day }\end{array}$ & 12 & 9 & 2 & 2 \\
\hline 16 & $\begin{array}{l}\text { I fill my free time by playing with a mobile } \\
\text { phone }\end{array}$ & 3 & 12 & 6 & 4 \\
\hline 17 & $\begin{array}{l}\text { Playing using a mobile phone is the best } \\
\text { time }\end{array}$ & 10 & 11 & 3 & 1 \\
\hline 18 & $\begin{array}{l}\text { I play a game from a mobile phone so I } \\
\text { don't miss another friend }\end{array}$ & 3 & 9 & 6 & 7 \\
\hline 19 & $\begin{array}{l}\text { I do not want to take turns with friends } \\
\text { when playing using a mobile phone }\end{array}$ & 13 & 8 & 3 & 1 \\
\hline 20 & $\begin{array}{l}\text { Saya lebih senang bermain mobile phone } \\
\text { daripada bermain di luar rumah bersama } \\
\text { teman }\end{array}$ & 11 & 6 & 4 & 4 \\
\hline \multicolumn{2}{|c|}{ Total Score } & 107 & 195 & 112 & 86 \\
\hline \multicolumn{2}{|c|}{ Average (student) } & 5,4 & 9,8 & 5,6 & 4,3 \\
\hline \multicolumn{2}{|c|}{ Percentage $(\%)$} & $21 \%$ & $39 \%$ & $22 \%$ & $17 \%$ \\
\hline
\end{tabular}

Based on the results of the recapitulation of a questionnaire written by fourth grade students of SD Muhammadiyah 1 Kudus, it was found that there were not many students indicated nomophobia because of a total of 25 students, around 16 students or $60 \%$ did not experience the habit or frequency of using mobile phones. Students indicated nomophobia were 4 students or $17 \%$ of the total 25 students due to high intensity or always using mobile phones for games and some 5 students or $22 \%$ of 25 students with intensity often used mobile phones. Although it does not reach $50 \%$, this condition must be observed and anticipated so that no more serious negative impacts occur. More clearly, table 1 is included in the diagram which can be attached to Figure 1 . 


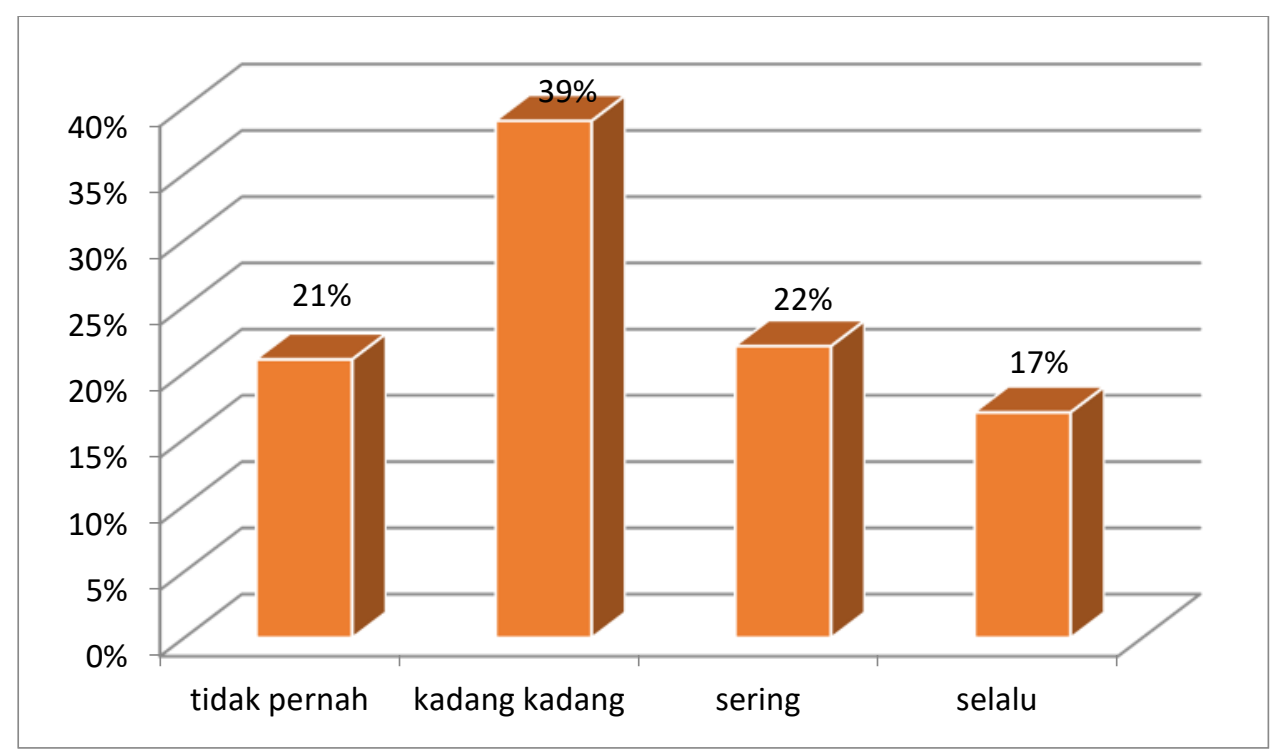

Figure 1. Diagram of Identification of Mobile Phone Usage

The identification of the use of mobile phones is carried out to find out children's activities in daily life related to their intensity of using a mobile phone. Activities undertaken by students related to nomophibia indicators that need to be watched are: a) happy to win the game, b) happy when they can level up the game, c) laugh and be entertained while playing the game, d) always fill the free time with games from mobile phones and e ) use a mobile phone to play games so as not to miss with his friends. Thus it can be seen that playing mobile phone is entertainment for children and is a trend to be able to exist with their friends.

Based on the results of the questionnaire recapitulation above it is also known that negative behavior is carried out by students for example: a) forgetting themselves and not caring about others when playing mobile phone, b) refusing parents when playing mobile phone, and c) preferring to play mobile phone rather than playing outdoors with friends. This must be resolved even though there are not many student identification results indicated dependency. Because something small if not immediately followed up if it continues to be done and becomes a habit, it will be difficult to stop it. Likewise with the use of mobile phones if it is not anticipated and maintained from an early age will become a dependency and even addicted to children (nomophobia) and of course the handling will be more difficult.

The dangerous thing is that by playing mobile phone students do not want to care about anyone around them. Because children already feel absorbed and entertained that they assume everything around them is not important. Even worse is if a child closes himself up while playing a mobile phone, and prefers to play alone using his mobile phone rather than playing with his friend so that he becomes an anti-social child so that it is very dangerous for his brain and psychological development. This agrees with Durak (2018) that smartphone with their constantly evolving features, facilitating instant communication and helping individuals stay connected with the world at all times.

Referring to this research, in addition to identifying the child's dependency on using a mobile phone (nomophobia), identification was made related to friendly character behavior. It is feared that children who excessively use a mobile phone will experience symptoms of reduced intensity of their mingling with friends. The result is because they feel more 
entertained playing using a mobile phone rather than meeting and hanging out with friends. Thus the filling out of student questionnaires related to friendly character behavior in daily life. The recapitulation results of friendly behavior questionnaire for grade IV students can be seen in the following Table 2.

Table 2. Recapitulation of Friendly Character Questionnaire In 4th-grade students of Muhammadiyah 1 Primary School Kudus

\begin{tabular}{|c|c|c|c|c|c|}
\hline \multirow[b]{2}{*}{ No } & \multirow[b]{2}{*}{ Statement } & \multicolumn{4}{|c|}{ choice } \\
\hline & & never & rarely & $\begin{array}{l}\text { Someti } \\
\text { mes }\end{array}$ & always \\
\hline 1 & $\begin{array}{l}\text { Have you ever seen the teacher / teacher } \\
\text { chatting with students during recess }\end{array}$ & 1 & 7 & 8 & 9 \\
\hline 2 & I dare tell my heart to the teacher & 3 & 11 & 6 & 5 \\
\hline 3 & $\begin{array}{l}\text { When talking with others I speak polite } \\
\text { language }\end{array}$ & & 14 & 11 & \\
\hline 4 & $\begin{array}{l}\text { When talking with others I speak polite } \\
\text { language }\end{array}$ & & 12 & 10 & 3 \\
\hline 5 & I will not mock my friend who has flaws & 4 & 9 & 7 & 5 \\
\hline 6 & I can be trusted to keep a friend's secret & 3 & 6 & 9 & 7 \\
\hline 7 & $\begin{array}{l}\text { When you play and find that one of your } \\
\text { friends has fallen because he tripped on a } \\
\text { rock, you will hurry to help him }\end{array}$ & 8 & 7 & 8 & 2 \\
\hline 8 & $\begin{array}{l}\text { After exercising I want to share a drink with } \\
\text { friends who don't bring drinks }\end{array}$ & 9 & 10 & 5 & 1 \\
\hline 9 & $\begin{array}{l}\text { When there are new friends in the school who } \\
\text { come from outside the area I immediately } \\
\text { invited him to get acquainted and play } \\
\text { together }\end{array}$ & 6 & 10 & 5 & 4 \\
\hline 10 & I am not picky about friends & 13 & 9 & 3 & \\
\hline \multicolumn{2}{|c|}{ Total Score } & 107 & 195 & 112 & 86 \\
\hline \multicolumn{2}{|c|}{ Average (student) } & 5,4 & 9,8 & 5,6 & 4,3 \\
\hline \multicolumn{2}{|c|}{ Percentage $(\%)$} & $21 \%$ & $39 \%$ & $22 \%$ & $17 \%$ \\
\hline
\end{tabular}


Table 2. Recapitulation of friendly character behavior can be seen in Figure 2 below.

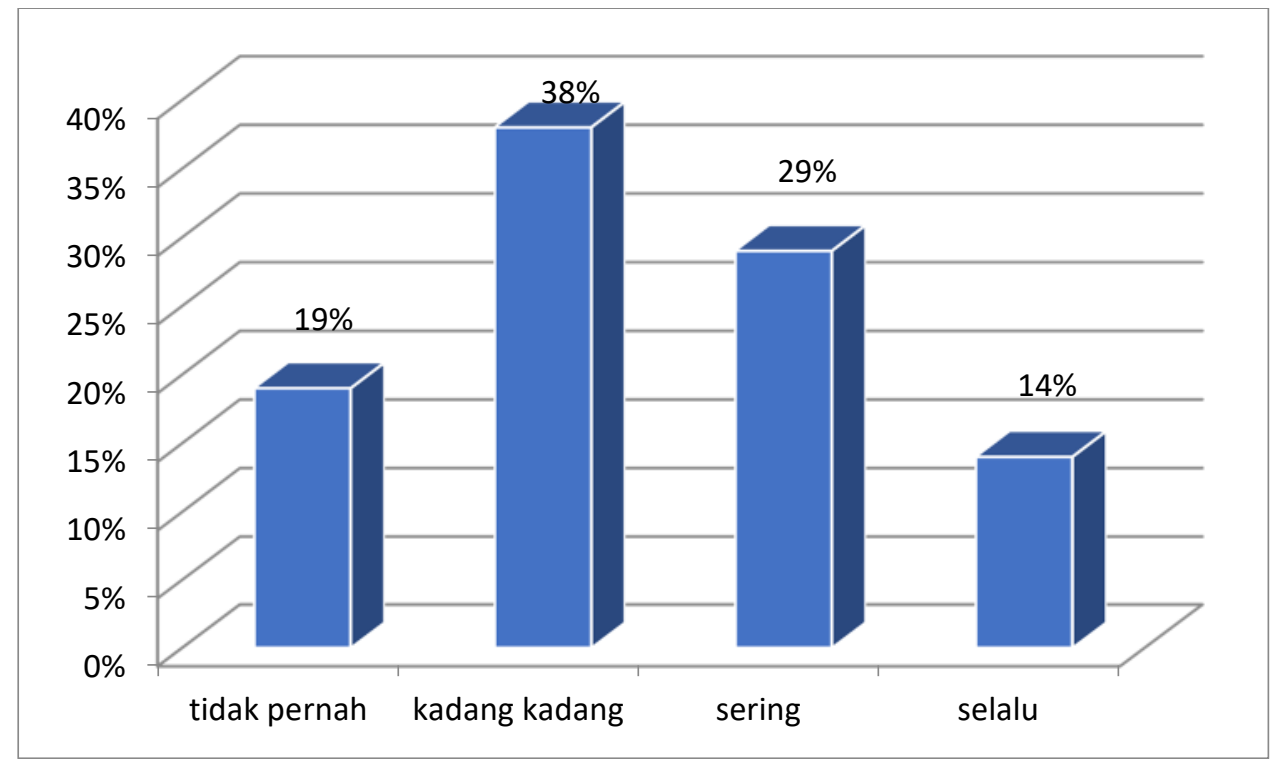

Figure 2. Friendly Character Behavior Diagram

Based on the recapitulation of the friendly character questionnaire in Kudus, SD Muhammadiyah 1 is still relatively low. It can be seen that from a number of indicators written on low criteria, namely with an intensity of $21 \%$ or 5 students and $39 \%$ or 10 students admit they have never and only occasionally take positive action in accordance with the friendly indicators. While those who have been able to behave positively according to indicators of character behavior are $43 \%$ or a total of 10 students out of a total of 25 students.

Friendly character behavior that is known from the results of questionnaires for fourth grade students of SD Muhammadiyah still needs to be improved and improved in the following aspects: a) do not dare to tell the teacher, b) speak politely to others, c) need to be trained in behavior, please help and share with others. Based on the results of the data obtained from student questionnaires it is known that there is a tendency of the names of students who hooby play games using a mobile phone it also has a higher individualistic nature than other friends.

Data supporting identification of nomophobia and friendly character behaviors obtained apart from the results of student questionnaires were from interviews with Class IV Teachers of SD Muhammadiyah 1 Kudus. Class IV teacher at SD Muhammadiyah 1 Kudus Mr. AR as the informant said that students at the school were not allowed to bring a mobile phone while learning took place. However, if to support and learn learning materials, new teachers instruct them to bring it to school. During the break period after the midterm or final semester assessment students are allowed to bring a mobile phone for communication to parents regarding school time.

The teacher said that basically there were no students who were addicted to using cellphones because they could still be controlled and advised, but there were indeed students who were very hobby and excited when given the opportunity to bring a mobile phone. Some 
of these students will gather into one and be excited to play it. Lack of control over emotions when playing mobile phone. Sometimes it is seen that there are students who are excited and at odds because of the game.

Based on the results of the questionnaire recapitulation that was obtained, interviews were conducted with students who indicated excessive use of mobile phones. The student stated that he felt very happy when playing mobile phone, even without playing for hours because of the excitement of playing sometimes to forget to take a shower. He felt emotions when engrossed in play suddenly had to stop parents. If told to choose to play in the field by playing using a mobile phone, then he prefers to play mobile phone because he is not tired.

\section{Conclution}

Based on preliminary research to analyze the needs of fourth grade students of SD Muhammadiyah 1 Kudus it can be concluded that from the results of identification there are some students who fabricate or indicate dependency on using a mobile phone as a means of entertainment, when there is an opportunity and free time students prefer to play using a mobile phone rather than playing games with physical activity with his friends. As a result, friendly character behavior is not optimal in the association of children. In the child becomes more prominent individual attitude than social attitude. With the existence of such preliminary data, further research is needed to know this in more detail.

\section{Acknowledgments}

Based on preliminary research to analyze the needs of fourth grade students of SD Muhammadiyah 1 Kudus it can be concluded that from the results of identification there are some students who fabricate or indicate dependency on using a mobile phone as a means of entertainment, when there is an opportunity and free time students prefer to play using a mobile phone rather than playing games with physical activity with his friends. As a result, friendly character behavior is not optimal in the association of children. In the child becomes more prominent individual attitude than social attitude. With the existence of such preliminary data, further research is needed to know this in more detail.

\section{References}

[1] Bragazzi, N.L., \& Del Puente. G. 2014. A proposal for including nomophobia in the new DSM-V. Psychology Research and Behaviour Management, 7: 155-160

[2] Chusna, I.A. 2017. Pengaruh Media Gadget Pada Perkembangan Karakter Anak. Dinamika Penelitian: Media Komunikasi Sosial Keagamaan. 17(2): 315 - 330

[3] Dahlia., dkk. 2017. Pengaruh Penggunaan Handphone Terhadap Perkembangan Karakter Anak Pada Usia Sekolah Dasar di SDN 20 Kota Banda Aceh. Jurnal Ilmiah Pendidikan Guru Sekolah. 2(4): 143 - 149

[4] Durak, H., Y. 2018. What Would You Do Without Your Smartphone? Adolescents' Socia Media Usage, Locus of Control, and Loneliness as a Predictor of Nomophobia. The Turkish Journal On Addictions. 5 (2): 1-15

[5] Hasan, dkk. 2010. Pengembangan Pendidikan Budaya dan Karakter Bangsa. Jakarta: Balitbang

[6] Jati dan Herawati. 2014. Segmentasi Mahasiswa Program Studi Ilmu Komunikasi UAJY dalam Menggunakan Gadget. E-Journal UAJY 
[7] King, A.L.S., Valenca A.M., Silva, A.C.O, Baczynski, Carvalho, M.R., Nardi, A.E. 2013. Dependnecy on Virtual Environments or Social Phobia?. Journal Homepage: www.elseviesr.com/locate/comphumbeh, 29 (2013): 140-144

[8] Latubessy dan Wijayanti. 2017. Model Identifikasi Kecanduan Game Menggunakan Backward Chaining. Jurnal Simetris, 8 (1) : 9 - 14

[9] Lemmens, J.S., Valkenburg, P.M., Peter J. 2009. Development and Validation of a Game Addiction Scale for Adolencents. Media Psychology, 12 (1): 77 - 95

[10] Manumpil., dkk. 2015. Hubungan Penggunaan Gadget dengan Tingkat Prestasi Siswa di SMA NEGERI 9 Manado. Ejoural Keperawatan, (Online), Vol. 3, No. 2, dalam http://ejournal.unsrat.ac.id diakses 20 Januari 2017)

[11] Muslich.,M 2011. Pendidikan Karakter; Menjawab Tantangan Krisis Multidimensional. Jakarta: Bumi Aksara

[12] Pavithra, M. B., Madhukurmar, S., \& Mahadeva, M. 2015. A study on nomophobiamobile phone dependence, among students of a medical college in Bangalore. National Journal of Community Medicine, 6(3): 340-344

[13] Pratiwi, Masfuah, Rondli. 2017. Pendidikan Multikultural Berbantuan Metode Pictorial Riddle Untuk Meningkatkan Karakter Kreatif dan Bersahabat Siswa Kelas 3 Sekolah Dasar. Scholaria: Jurnal Pendidikan dan Kebudayaan, 7 (2): 109-119

[14] Pratiwi, IA., and Masfuah, S. 2018. Improving Frienly Character Through Traditional Game of The Engklek at The Thematic Learning. Prceeding EUDEL

[15] Sugiyono. 2013. Metode Penelitian Pendidikan (Pendekatan Kuantitatif, Kualitatif, dan $R \& D)$. Bandung : Alfabeta

[16] Widiawati, I, Sugiman, H \& Edy. 2014. Pengaruh Penggunaan Gadget Terhadap Daya Kembang Anak. Jakarta: Universitas development

[17] Yildirim, C. 2014. Exploring the Dimensions of Nomophobia: Developing and Validating a Questionnaire Using Mixed Methodsresearch. Graduate These and Dissertations. Paper 14005 